\title{
The Degree Represent of the Faculty Members in Official Jordanian Universities for the Human Relation Amongst them (University Collegiality) as a Professional Ethical Behavior
}

\author{
Maram Fuad Abu Al-Nadi ${ }^{1}$ \\ ${ }^{1}$ Department of Education, Petra University, Amman, Jordan \\ Correspondence: Maram Fuad Abu Al-Nadi, Department of Education, Petra University, Amman, Jordan. Tel: \\ 962-796-283-454. E-mail: doctornadi@yahoo.com
}

Received: July 9, 2018

Accepted: July 19, 2018

Online Published: August 27, 2018

doi:10.5539/mas.v12n9p209

URL: https://doi.org/10.5539/mas.v12n9p209

\begin{abstract}
This study aims at identifying the degree represent of the faculty members in official Jordanian Universities for the human relation among them (University Collegiality) as a professional ethical behavior, the survey methodology has been used in this study, and developed questionnaire consists of (26) paragraphs, and the tool has been verified its validity and reliability. The study sample consisted of official Jordanian universities' members represented by the universities of Jordan, Yarmouk and Mutah, a total of (300) member, were selected in a simple random method, and the study concluded the following results:

The Arithmetical averages and standard deviations showed that the degree of represent the faculty members in official Jordanian Universities for the human relation among them (University Collegiality) as a professional ethical behavior it was a medium degree.

The result showed statistically significant differences at the significance level $(\mathrm{p}=0.05)$ in the estimates of the study sample members for the degree represent of the faculty members in official Jordanian Universities for the human relation among them (University Collegiality) as a professional ethical behavior, it referred to gender variable, and it was in favor of males, the results also showed statistically significant differences for the faculty class and it was in favor of sciences faculties, also showed statistically significant differences for the academic rank and it was in favor of associate Professor rank.

The study recommended to focus on the subject of the University Collegiality among the faculty members and develop an agreement of the university collegiality in participation of official and unofficial Jordanian universities.
\end{abstract}

Keywords: faculty members, official Jordanian universities, human relations, university collegiality, Professional Ethics

\section{Introduction}

The universities are pioneer community educational institutions, connected to ministry of Higher Education, they are beacons of sciences and knowledge, seeking in its' vision and mission to achieve high level and distinctive education. They also, support and execute the higher education institutions policies and strategies and are working on achieving the competitive advantages, in addition to achieve Justice, transparency and distinctive services of university system inputs.

The official universities providing variety of missions such as distinctive education to produce educational elites; capable of joining the labor market, as well as creating scientific researchers who are well qualified in all contemporary issues at the local, Arab and global levels and community service. The official Jordanian universities contribute to openness with the local society and strengthen ties and links with it. And has a major role in contributing in solving its problems, achieving its sustainable development, goals and aspirations. It also spread knowledge amongst faculty members (Halalat, Adayla, 2017).

There are many higher education inputs; one of them is the university academic staff, upon them depend the reputation and excellence of the university; they are in charge of graduating and raising a well-informed and educated generation. As each profession has its own ethics, education profession has shape students character with adherence to good morals, and prepare them to be decisions makers, and this is possible only in a university 
environment that respects the ethics of the teaching profession which derived from community ethics, customs and traditions, and providing educational environment with collegiality university among faculty members during their academic professions based on respect, appreciation and prevalence of the human relations, which contribute to increase the competitive advantage of the University (Rawashdeh, 2017).

The faculty member in the official universities has many tasks and responsibilities; teaching, writing papers, adhering to their code of ethics towards his colleagues. In addition to commitment of the teaching profession ethics based on awareness of what his right and what his responsibility, and his human responsibility toward his job mates. Accomplishing his duty in the best way. Dedicated honestly and faithfully to his mission, and refrain from taking advantage of his job to achieve other purposes. He should share his knowledge experiences with his colleagues and to be honest and faithful in his work, respect his colleagues, and provide a positive perspective in the academic community that he is belonging to, he should show no depravity or conflicts because it affect the teaching profession ethics (Abu Hussein, 2014).

Like many other aspects, teaching career has its own code of ethics, which should be retained with university collegiality on the one hand, and the students' community on the other. Academic staff should refrain from directing any insults to his colleagues, or playing off some of them against the others, in a manner, which might create an enmity among them. Their most concern should be concentrated on achieving their institute's goals. This requires always defending them and pushing towards a better relation between them. (Balawi, 2007)

A distinguished relations between universities staff (university collegiality), is of mutual influence, and as much as each fellow shows his profession of respect and appreciation to his colleagues, the best will be the benefit between the university community. Encouraging colleagues to foster them leads to enhanced trust among themselves, and this would usually accumulate and increase through sharing of their experiences among faculty members are based on the principle of university collegiality which includes the impact in the relation between faculty members and their other colleagues, and self-confidence by participation the colleagues in them experiences and knowledge. Once that happened it will be reflected positively on all, institutions ( universities), individuals ( academic staff) and students receiving science, Similarly, this will generate more confidence to those who newly engaged in the profession, for they would benefit what has been provided to them by the experts ( the old colleagues) vis-à-vis development and progress . (Dirani\&Alshdooh, 2016).

Strong ties between university staff is of great importance in raising their morals and fulfill their needs, which leads to the fulfillment of complacency and safety by achieving justice and freedom, and encourage them to express their opinion with courage. It would lead them also, to perform their duties with high professionalism as a one team. Good ties between academic staff would pave the way to create an idol-learning atmosphere, which would lead to perfectionism when it comes to learning and teaching. This process, whoever, would enhance the university' reputation and help it to achieve its goals on the one hand, and balance between these goals and the satisfactions of its faculty members on the other. Doing so, would help the institute to identify strengths and weaknesses within the academic process, so they can enhance the strengths and addressing weak issues to improve them and raise their efficiency (Daya, Abu Rish, 2017).

Interest in the university collegiality is very important subject, because the human relations based on university collegiality is no longer a luxurious aspect but rather a necessity one, to enhance the capability and increase its efficiency and competency. It is no longer a matter of do or undo business, but it should be built on a solid base, taking in consideration the framework of the real academic work that depends on the profession's code of ethics. (Al-Rubaie, 2008).

It should be noted, however, that relationship between colleagues in the universities nowadays does not exceed the words of courtesy. This is far from been workable or even acceptable amongst job mates. To address this issue, this study will investigate the human relations between universities' academic staff (university collegiality) as an ethical behavior.

\subsection{Problem of Study}

Research problem has been represented in answering the following question:

What is the degree represent of the faculty members in official Jordanian Universities for the human relation among them (University Collegiality) as a professional ethical behavior?

\subsection{Objective and Questions of Study}

This study aimed to identify the degree represent of the faculty members in official Jordanian Universities for the human relation among them (University Collegiality) as a professional ethical behavior, to achieve this objective the study's questions were answered: 
In order to answer this question, the arithmetical averages and standard deviations of the study sample were calculated to the degree which represents the faculty members of the official Jordanian universities for human relations among them (University Collegiality) as a professional ethical behavior according to the variable of the academic rank. The results were as follows:

Table 5. The arithmetical averages and the standard deviations of the study sample to the degree which represents the faculty of human relations among them (University Collegiality) as a professional ethics according to the variable of the academic's rank

\begin{tabular}{llll}
\hline Academic rank & No. & Arithmetical average & Standard deviation \\
\hline Professor & 100 & 1.94 & 0.464 \\
Associate professor & 110 & 2.2 & 0.415 \\
Assistant professor & 90 & 2.12 & 0.484 \\
\hline
\end{tabular}

Table (5) shows the apparent existence of the differences in the study sample to the degree which represents the faculty members of the official Jordanian universities for human relations among them (university collegiality) as a professional ethical behavior according to the variable of the academic rank. In order to find these differences, the mono-variance test was followed and the results were as follows:

Table 6. To examine the significance of the differences in the study sample to the degree which represents the faculty members of human relations among them (University Collegiality) as a professional ethical behavior according to the variable of the academic's rank

\begin{tabular}{llllll}
\hline Significance level & (F) value & Squares average & Freedom degrees & Squares total & Variance source \\
\hline 0.000 & 10.247 & 2.106 & 2 & 4.212 & Between groups \\
& & 0.206 & 297 & 61.046 & Within groups \\
& & & 299 & 65.259 & Total \\
\hline
\end{tabular}

Table (6) shows that there are statistically significant differences at a significance level less than (0.05) in the study sample to the degree which represents the faculty members in the official Jordanian universities for human relations among them (university collegiality) as a professional ethical behavior according to the variable of the academic rank. These differences have been tested (LSD) For comparison and the results were as follows:

Table 7. (LSD) test to compare the categories of the academic rank in the study sample to the degree which represents the faculty members for human relations among them (university collegiality) as a professional ethical behavior

\begin{tabular}{llll}
\hline Academic rank & Arithmetical average & Associate professor & Assistant professor \\
\hline professor & 1.99 & $*$ & $*$ \\
Associate professor & 2.22 & & \\
Assistant professor & 2.07 & $*$ & \\
\hline
\end{tabular}

It is clear from Table (7) that there are statistically significant differences at the significance level (0.05) in the study sample to the degree that represents the faculty members in the official Jordanian universities for human relations among them (university collegiality) as a professional ethical behavior among the rank of (Associate Professor), and each of the professor and Assistant Professor rank, in favor of the Associate Professor rank.

Question 2: Are there statistically significant differences in the estimates of the study sample members for the degree represent of the faculty members in official Jordanian Universities for the human relations among them (University Collegiality) as a professional ethical behavior, referred to variable of gender, faculty class and academic rank?

\subsection{Importance of Study}

The importance of this study stems from the importance of the subject namely: human relation (University Collegiality) as a Professional Ethical Behavior. The researcher hope that the results of this study will benefit the following entities 
- Universities' chair persons: - Through improving the educational process outputs, and to confront the negative and corrected.

- Researchers: through providing them with theoretical framework regarding the degree represent of the faculty members in official Jordanian Universities for the human relation among them (University Collegiality) as a professional ethical behavior and research tool.

\subsection{Definition}

Faculty members: PHD holders of all ranks who are teaching in Jordanian universities including lecturers, assistant, associate and full professors. (Rawashdeh, 2017).

Faculty members: persons who teach in the Jordanian Universities with a doctorate degree, and their academic ranks differ between lecturer, assistant professor, associate professor and professor

Official Jordanian Universities: community educational institutions, connected with the Ministry of Higher Education in Jordan, and are determined in this study by Yarmouk University in the north, the University of Jordan in the center, and Mu'tah University in the south.

Human relations: "A set of processes which motivate a faculty member in a particular position leads to a balance between the institution and individual objectives" (Alwadyan, 2016)

University Collegiality: it is an ethical professional behavior between the faculty members at the official Jordanian Universities, which aim at achieving the balance between own faculty member's objectives and Universities' ones through benefitting from their variety skills and experiences in an atmosphere of affection and love of appreciation and respect.

Professional Ethical Conduct: A set of principles, bases and ideals that the members of the profession are committed to in practicing their profession in order to preserve the rights of their members (Hassan, 2017).

\subsection{Limitation}

This study limited to:

Human limits: faculty members in the official Jordanian universities, the University of Jordan, Yarmouk University and Mu'tah University.

Time limits: the study is confined itself with faculty members in the official Jordanian Universities of the academic year 2017-2018.

Spatial limits: determined in this study by Yarmouk University in the north, the University of Jordan in the center, and Mu'tah University in the south.

\subsection{Previous Related Research}

Following; are some of the relevant studies, which have been chronologically arranged from the oldest to the most recent and as follows:

Alashqar, and Allaoh (2012) developed a research "The degree of practice of a faculty member in the Palestinian universities; the human relations from the perspective of his students" this study aimed to identify the degree of practice of a faculty member in the Palestinian universities the human relations from the perspective of his students, and this study used the descriptive analytical method, with a questionnaire as a study tool, the study community consisted of all students of Al-Quds Open University and Islamic University. The study results showed that the degree of practice of a faculty member in the Palestinian universities of the human relations from the perspective of his students was in high level, it has also, found differences in favor of male as concerning Gender, and in favor of Humanities field as concerning faculties.

Another study in this field was conducted by Alalawneh (2015) titled " The social relations between faculty members and students at the Faculty of Sports Sciences at Mu'tah University from the students' perspective" this study aimed to identify the social relations between faculty members and students at the Faculty of Sports Sciences at Mu'tah University from the students' perspective, the study used the descriptive analytical method, with a questionnaire as a study tool, the study community consist of faculty members and Faculty of Sports Sciences' students at Mu'tah University. The study results showed that the social relations between faculty members and students at the Faculty of Sports Sciences at Mu'tah University from the students' perspective was in high level, it has also, found differences in favor of Gender favoring the mails.

Terosky, lapointe, Chris, (2015) conducted a study titled "Support online college through a sense of community and Collegiality" it was a qualitative study, and the study sample consists of Seven of the current and future faculty 
members to know their sense of scientific surrounding community. The participants stated that their sense of community and collegiality was weak, for participants of the on line educational communities are focusing primarily on technical support, in addition to their interest in philosophical and psychological aspects with the availability of online teaching.

Another study conducted by Alwiyan (2016) titled " Human relations prevailing among a sample of faculty members at Salman bin Abdulaziz University and its relationship with job performance" this study aimed to identify the human relations prevailing among a sample of faculty members at Salman bin Abdulaziz University and its relationship to job performance, this study used the descriptive analytical method, with a questionnaire as a study tool. The study community consists of faculty members at Salman bin Abdulaziz University, the study results showed the existence of a significant correlation between human relations and job performance among faculty members at Salman bin Abdulaziz University, they also have the human relations dimensions in a great extent.

Derani \& Alshdooh (2016) conducted a study titled "The level of Collegiality between faculty members at Jerash University: case study" aimed to evaluate the level of collegiality between faculty members at Jerash University. This study used the descriptive analytical method, with a questionnaire as a study tool. The study community consists of faculty members at Jerash University, its results showed that the faculty members are familiar with the Collegiality concept, and no statistically significant differences have been observed depending on gender, academic rank, age, or experience.

Bruce (2016) conducted a study titled "Collegiality and performance in competitive academic culture". It considered that the Collegiality is one of the most important keys in the higher education, and aimed to understand the perceptions of structural, cultural and behavioral collegiality among academics at Hong Kong universities, the study used the questionnaire as a tool, its results showed that it is still being adopted as a core value in the leading research universities in Hong Kong, and no statistically significant differences have been observed depending on gender and academic rank.

Iman, Aldayeh, and Reem Abo Alreesh (2017) conducted a study titled " The degree of practice in education faculties in Palestine universities, for the standards of work ethic and way to develop it" the study aimed to identify the degree of practice of the education faculties in the Palestinian universities to the standards of work ethic and way to develop it. This study used the descriptive analytical method, with a questionnaire as a study tool. The study community consists of faculty members in education faculties at Palestinian universities. Its results showed that the degree of practice of the faculties of education in the Palestinian universities to the standards of work ethic became in a medium degree, there were also differences in favor of the university, and no statistically significant differences have been observed depending on gender and academic rank.

Alhalalat, Aladayleh (2017) conducted a study titled " The degree of commitment of faculty members in the social service departments in Jordanian universities to the ethics of the education profession from the students' perspective: the university of Jordan and Al- Balqa' Applied University" this study aimed to identify the degree of commitment of faculty members in the social service departments in Jordanian universities to the ethics of the education profession from the students' perspective it used the descriptive analytical method, and a questionnaire as a study tool. The study community consists of faculty members at the university of Jordan and Al- Balqa' Applied University. The study showed the degree of commitment of faculty members in the social service departments in Jordanian universities to the ethics of the education profession from the students' perspective is in high level, there were also differences according to gender variable and were in favor of females, and there were differences in favor of Al- Balqa' Applied University.

Sophia, Kevin (2017) conducted a study titled " Effect of Collegiality and its relation to the academic performance among the Australian Academy of Accountants" the study sample consists of the professional academics at the Australian Universities, applying a questionnaire as a study tool, the study results showed that there is a positive correlation between the collegiality and academic performance, and the level of collegiality is linked to positive organizational performance of the employee.

Alautaibi (2017) conducted a study titled "The degree of commitment of faculty members at the Faculty of Education in Al-Dawadmi to the professional ethics from the perspective of his students" this study aimed to identify the degree of commitment of faculty members at the Faculty of Education in Al-Dawadmi to the professional ethics from the perspective of his students, the study used a comprehensive survey method, and a questionnaire as a study tool, the study. The study results showed that the degree of commitment of faculty members at the Faculty of Education in Al-Dawadmi to the professional ethics from the perspective of his students was in medium level, and there were no statistically significant differences in favor of major. 
A study has been conducted by Blankeship, Platt, Hannah (2017) titled " Reward colleagues use of Collegiality as a factor in faculty assessment and hiring decisions" The faculty members were evaluated as part of their promotion in three main fields: research, education, service, and Collegiality as a fourth measure on the dynamics of the faculty members, the study community consists of faculty members in colleges and universities in the United States of America. The results showed that the Collegiality factor should be used as a factor in performance reviews.

\subsection{What Distinguishes this Study from Previous Studies?}

The previous Arab and foreign studies were used in terms of theoretical literature, the used tool, and the choice of study methodology, as Al -Outabi study (2017), Al Wedian study (2016), Alawneh study (2015). What distinguishes this study from the previous ones is that it deleted the degree of the reality that representing the faculty members of the official Jordanian universities from their point of view. This study is similar to the foreign studies in concept. It is similar to the study of Dirani and Shadooh (2016), but it is the first study in the Arab world that examined the subject of university Collegiality in the human relations (university Collegiality) to the knowledge of the researcher.

\section{Methodology}

The study followed the descriptive approach as the most appropriate for this type of studies.

\subsection{Population of the Study}

The population of this study is composed of faculty members in the official Jordanian universities, mainly, the University of Jordan, Yarmouk, and Mu'tah University, for the academic year 2017-2018, the number of faculty members of these universities is (10129) according to the statistics of the Ministry of the Higher Education and Scientific Research 2017-2018.

\subsection{Sample of the Study}

A simple random sample consisting of (300) faculty members were taken, and Table (1) shows this:

Table 1. Distribution of sample members according to university, gender, type of college, and academic rank

\begin{tabular}{|c|c|c|c|c|c|c|c|c|c|c|}
\hline \multirow{2}{*}{$\begin{array}{l}\text { Total } \\
\%\end{array}$} & \multicolumn{3}{|c|}{ Mutah university } & \multicolumn{2}{|c|}{ Yarmouk university } & \multicolumn{2}{|c|}{ The university of Jordan } & \multirow{2}{*}{$\begin{array}{l}\text { university } \\
\text { Gender }\end{array}$} & \multirow{2}{*}{ Rank } & \multirow[b]{2}{*}{ Type of collage } \\
\hline & No. & $\%$ & No. & $\%$ & No. & $\%$ & No. & & & \\
\hline 10.0 & 30 & 1.3 & 4 & 4.0 & 12 & 4.7 & 14 & male & \multirow{2}{*}{ professor } & \multirow{8}{*}{ Scientific } \\
\hline 6.3 & 19 & 2.3 & 7 & 1.7 & 5 & 2.3 & 7 & female & & \\
\hline 12.0 & 36 & 2.7 & 8 & 4.3 & 13 & 5.0 & 15 & male & \multirow{3}{*}{ Associate professor } & \\
\hline 8.0 & 24 & 2.0 & 6 & 2.7 & 8 & 3.3 & 10 & female & & \\
\hline 10.3 & 31 & 3.7 & 11 & 2.3 & 7 & 4.3 & 13 & male & & \\
\hline 8.3 & 25 & 2.0 & 6 & 4.0 & 12 & 2.3 & 7 & female & Assistant professor & \\
\hline 9.3 & 28 & 2.0 & 6 & 2.7 & 8 & 4.7 & 14 & male & \multirow{2}{*}{ Professor } & \\
\hline 7.7 & 23 & 2.7 & 8 & 3.3 & 10 & 1.7 & 5 & female & & \\
\hline 10.3 & 31 & 2.7 & 8 & 4.3 & 13 & 3.3 & 10 & male & A scociate profescor & \multirow{4}{*}{ Humanities } \\
\hline 6.3 & 19 & 2.7 & 8 & 2.0 & 6 & 1.7 & 5 & female & Assoltale piotessol & \\
\hline 5.7 & 17 & 2.3 & 7 & 2.0 & 6 & 1.3 & 4 & male & \multirow{3}{*}{ Assistant professor } & \\
\hline 5.7 & 17 & 2.0 & 6 & 1.7 & 5 & 2.0 & 6 & female & & \\
\hline 100.0 & $\begin{array}{l}30 \\
0\end{array}$ & 28.3 & 85 & 35.0 & 105 & 36.7 & 110 & Total & & \\
\hline
\end{tabular}

\subsection{Study Instrument}

This study aimed to identify the degree which represents the faculty members of the official Jordanian universities for the human relations among them, (University collegiality) as a professional ethical behavior, in order to achieve the study objective and to answer its questions, which has been referred to the theoretical literature which related to the subject of the study and the previous studies , such as Alhalalat study, Al-adaylah (2017), Aldaya, and Abualrish(2016),the questionnaire has been built of (26 paragraph). The Likert Scale was used as follows: To a large degree, moderately to a small degree.

\subsection{Questionnaire Validity}

The questionnaire was presented to ten arbitrators in the field of educational administration, to ensure their validity in the terms of construction, language, integrity and clarity, and the notes of all arbitrators were taken. 


\subsection{Questionnaire Reliability}

To verify the reliability of questionnaire, the Cronbach's-alpha coefficients was calculated for the questionnaire paragraphs (0.940).

\subsection{Study Variables}

The study included the following variables:

- The Independent variable: human relations (University Collegiality)

- The Dependent variable: the response degree of the faculty members of official Jordanian universities, which are the University of Jordan, Yarmouk University, and Mutah University.

- Intermediate variable

- Gender: it has two levels, the first one for male and the second for female.

- Type of college: it has two levels, scientific colleges and humanities colleges

- Academic rank: it has three levels, professors, Associate and Assistant professors.

\subsection{Statistical Processing Methods}

To meet study objectives, the statistical packages program for social sciences (SPSS) was used to analyze data and obtain the results as follows:

- The arithmetical averages and the standard deviations to identify the sample member's responses in each paragraph of questionnaire paragraphs.

- Cronbach's Alpha to verify the questionnaire stability

- (T test) For independent samples to know the significance of differences between two independent groups.

- Analysis of mono-variance (One-way ANOVA) to know the significance of differences between more than two independent groups.

- The less significant difference test (LSD) to compare between variable categories.

- Use the following staging to indicate the average responses of sample members: 2.34 and greater approval score, from 1.67 to less than 2.34 approval degrees medium, less than 1.67 approval degrees low.

\section{Study Result}

The results of the study are presented in accordance with their questions, as follow:

\subsection{Result Related to Question (1)}

What is the degree represent of the faculty members in official Jordanian Universities for the human relation among them (University Collegiality) as a professional ethical behavior?

To answer this question, the arithmetical averages, and standard deviations and the approval scores ranking of the sample were calculated in the questionnaire paragraphs. The results were as follows:

Table 2. Arithmetical averages, standard deviations, and order of the approval ratings of sample members in the questionnaires

\begin{tabular}{|c|c|c|c|c|c|}
\hline No. & Paragraph & $\begin{array}{l}\text { Arithmetical } \\
\text { average }\end{array}$ & $\begin{array}{l}\text { Standard } \\
\text { deviations }\end{array}$ & $\begin{array}{l}\text { Approval } \\
\text { degree }\end{array}$ & Ranking \\
\hline & & & & Big & \\
\hline 6 & The characterized of the collegiality relation is humanity & 2.38 & 0.746 & $\mathrm{i}$ & 1 \\
\hline 20 & $\begin{array}{l}\text { He does communication channels and communication } \\
\text { with colleagues }\end{array}$ & 2.34 & 0.744 & Big & 2 \\
\hline 14 & Spread the positivity among colleagues & 2.31 & 0.730 & Medium & 3 \\
\hline 21 & Spread the trust between colleagues & 2.27 & 0.726 & Medium & 4 \\
\hline
\end{tabular}




\begin{tabular}{|c|c|c|c|c|c|}
\hline 9 & Respect the opinion and others opinion & 2.24 & 0.795 & Medium & 5 \\
\hline 7 & Accept the constructive criticism from colleagues & 2.21 & 0.712 & Medium & 6 \\
\hline 3 & $\begin{array}{l}\text { He is keen to help the new colleagues and share the } \\
\text { knowledge with them }\end{array}$ & 2.18 & 0.719 & Medium & 7 \\
\hline 5 & avoid blaming colleagues in front of each other & 2.16 & 0.724 & Medium & 8 \\
\hline 4 & He loves to others what he loves for himself & 2.15 & 0.734 & Medium & 9 \\
\hline 25 & He uses polite language in dealing with colleagues & 2.13 & 0.736 & Medium & 10 \\
\hline 19 & he shows the respect to colleagues & 2.12 & 0.729 & Medium & 11 \\
\hline 13 & Maintains the university collegiality & 2.11 & 0.692 & Medium & 12 \\
\hline 1 & Humble to achieve the university collegiality & 2.10 & 0.746 & Medium & 13 \\
\hline 2 & Respects the colleague's opinion of faculty members & 2.09 & 0.757 & Medium & 14 \\
\hline 10 & Helps colleagues in solving problems & 2.08 & 0.730 & Medium & 15 \\
\hline 15 & Tends to the meaningful dialogue with colleagues & 2.07 & 0.752 & Medium & 16 \\
\hline 16 & Greetings to colleagues & 2.05 & 0.768 & Medium & 17 \\
\hline 22 & Keep away from hurting the colleagues & 2.04 & 0.791 & Medium & 18 \\
\hline 26 & Treat them gently away from transcendence & 2.03 & 0.730 & Medium & 19 \\
\hline 8 & Visits colleagues during the university hours & 2.01 & 0.715 & Medium & 20 \\
\hline 11 & Takes into consideration the colleagues feelings & 1.99 & 0.745 & Medium & 21 \\
\hline 12 & Provides advice and guidance to colleagues & 1.95 & 0.725 & Medium & 22 \\
\hline 18 & Interacts with the new colleagues & 1.92 & 0.738 & Medium & 23 \\
\hline 23 & keen to find good relations with colleagues & 1.91 & 0.679 & Medium & 24 \\
\hline 24 & Respects the feelings of colleagues not to hurt them & 1.88 & 0.735 & Medium & 25 \\
\hline \multirow[t]{2}{*}{17} & Shares the colleagues their various occasions & 1.84 & 0.789 & Medium & 26 \\
\hline & General average & 2.10 & 0.467 & & \\
\hline
\end{tabular}

The results show that the arithmetical averages in the sample approval degree on the questionnaire paragraphs ranged from1.84 to2.38. Whereas Paragraphs 6 and 20 received a high degree of approval, the highest of which was paragraph 6 (2.38), while the rest of the paragraphs received the lowest approval score (paragraph. 17). (Shares the colleagues their different occasions). (1.84). the table shows the total of paragraphs (2.10) and the average of the approval degree, this indicates that the degree which represents of the faculty members in the official Jordanian universities concerning the human relations among them (university collegiality).as a professional ethical behavior is medium.

\subsection{Result Related to Question}

(2): Are there statistically significant differences in the estimates of the study sample members for the degree represent of the faculty members in official Jordanian Universities for the human relations among them (University Collegiality) as a professional ethical behavior, referred to variable of gender, faculty class and academic rank?

\subsubsection{In order to Answer this Question}

The statistical averages and standard deviations of the study sample were calculated, to represent the faculty members of the official Jordanian universities, for human relations (university collegiality) as a professional ethical behavior according to the gender variable and the use of the "T" test to know the significance of the differences between these averages. As follows:

The results of " $\mathrm{T}$ " test for independent samples to know the significance of differences in the arithmetical averages of the degree which represent the faculty members of the official Jordanian universities for human relations among them (University Collegiality) as a professional ethical behavior according to the gender variable.

Table (3) shows that the value level of the significance is $(0.003)$ which is less than $(0.05)$. This indicates that there are statistically significant differences in the study sample to the degree which represents the faculty members in the official Jordanian universities, for human relations among them (University Collegiality), as a professional ethical behavior according to the gender variable, and from the arithmetic averages show that these differences were in favor of males.

Table 3. "T" test for independent samples to know the significance of differences in the arithmetical averages of the degree which represent the faculty members of the official Jordanian universities for human relations among them (University Collegiality) as a professional ethical behavior according to the gender variable. 


\begin{tabular}{lllllll}
\hline Gender & $\begin{array}{l}\text { Freedom } \\
\text { degrees }\end{array}$ & $\begin{array}{l}\text { Arithmetical } \\
\text { average }\end{array}$ & $\begin{array}{l}\text { Standard } \\
\text { deviation }\end{array}$ & $\begin{array}{l}\text { “T” } \\
\text { value }\end{array}$ & $\begin{array}{l}\text { Freedom } \\
\text { degrees }\end{array}$ & $\begin{array}{l}\text { Significance } \\
\text { level }\end{array}$ \\
\hline Male & 173 & 2.16 & 0.452 & 2.963 & 298 & 0.003 \\
Female & 127 & 2.00 & 0.474 & & & \\
\hline
\end{tabular}

\subsubsection{Result Related to Question (1)}

Are there statistically significant differences in the estimates of the study sample members for the degree represent of the faculty members in official Jordanian Universities for the human relations among them (University Collegiality) as a professional ethical behavior, referred to variable the type of the college?

In order to answer this question, the statistical averages and standard deviations of the study sample were calculated to the degree which represents the faculty members of the official Jordanian universities for human relations among them (university collegiality), as a professional ethical behavior according to the type of college variable and the use of the " $\mathrm{T}$ " test to know the differences between these averages. As follows:

Table 4. The results of the "T" test for independent samples to know the significance of differences in the arithmetical averages of the degree, which represents the faculty members of the official Jordanian universities for human relations among them (university collegiality) as a professional ethical behavior according to the variable of the type of college

\begin{tabular}{lclllll}
\hline Collage & No. & $\begin{array}{l}\text { Arithmetical } \\
\text { average }\end{array}$ & $\begin{array}{l}\text { Standard } \\
\text { deviation }\end{array}$ & $\begin{array}{l}\text { "T" } \\
\text { value }\end{array}$ & $\begin{array}{l}\text { Freedom } \\
\text { degrees }\end{array}$ & $\begin{array}{l}\text { Significance } \\
\text { level }\end{array}$ \\
\hline Scientific & 165 & 2.19 & 0.445 & 3.901 & 298 & 0.000 \\
Humanities & 135 & 1.98 & 0.470 & & & \\
\hline
\end{tabular}

Table (4) shows that the value level of the significance was $(0.000)$ which is less than $(0.05)$. This indicates that there are statistically significant differences in the study sample to the degree, which represents the faculty members of the official Jordanian universities for the human relations among them as a professional ethical behavior for the variable of the college type. This indicates that the views of faculty members in the scientific college to the degree which represents the faculty members of the official Jordanian universities for human relations among them (University Collegiality) as a professional ethical behavior were more than humanities colleges.

\subsubsection{Result Related to Question (2)}

Are there statistically significant differences in the estimates of the study sample members for the degree represent of the faculty members in official Jordanian Universities for the human relations among them (University Collegiality) as a professional ethical behavior, referred to variable of gender, faculty class and academic rank?

In order to answer this question, the arithmetical averages and standard deviations of the study sample were calculated to the degree which represents the faculty members of the official Jordanian universities for human relations among them (University Collegiality) as a professional ethical behavior according to the variable of the academic rank. The results were as follows:

Table 5. The arithmetical averages and the standard deviations of the study sample to the degree which represents the faculty of human relations among them (University Collegiality) as a professional ethics according to the variable of the academic's rank

\begin{tabular}{llll}
\hline Academic rank & No. & Arithmetical average & Standard deviation \\
\hline Professor & 100 & 1.94 & 0.464 \\
Associate professor & 110 & 2.2 & 0.415 \\
Assistant professor & 90 & 2.12 & 0.484 \\
\hline
\end{tabular}

Table (5) shows the apparent existence of the differences in the study sample to the degree which represents the faculty members of the official Jordanian universities for human relations among them (university collegiality) as a professional ethical behavior according to the variable of the academic rank. In order to find these differences, the mono-variance test was followed and the results were as follows: 
Table 6. To examine the significance of the differences in the study sample to the degree which represents the faculty members of human relations among them (University Collegiality) as a professional ethical behavior according to the variable of the academic's rank

\begin{tabular}{llllll}
\hline $\begin{array}{l}\text { Significance } \\
\text { level }\end{array}$ & $($ F) value & $\begin{array}{l}\text { Squares } \\
\text { average }\end{array}$ & $\begin{array}{l}\text { Freedom } \\
\text { degrees }\end{array}$ & Squares total & Variance source \\
\hline 0.000 & 10.247 & 2.106 & 2 & 4.212 & Between groups \\
& & 0.206 & 297 & 61.046 & Within groups \\
& & & 299 & 65.259 & Total \\
\hline
\end{tabular}

Table (6) shows that there are statistically significant differences at a significance level less than (0.05) in the study sample to the degree which represents the faculty members in the official Jordanian universities for human relations among them (university collegiality) as a professional ethical behavior according to the variable of the academic rank. These differences have been tested (LSD) for comparison and the results were as follows:

Table 7. (LSD) test to compare the categories of the academic rank in the study sample to the degree which represents the faculty members for human relations among them (university collegiality) as a professional ethical behavior

\begin{tabular}{llll}
\hline Academic rank & Arithmetical average & Associate professor & Assistant professor \\
\hline professor & 1.99 & $*$ & $*$ \\
Associate professor & 2.22 & & $*$ \\
Assistant professor & 2.07 & $*$ & \\
\hline
\end{tabular}

It is clear from Table (7) that there are statistically significant differences at the significance level $(0.05)$ in the study sample to the degree that represents the faculty members in the official Jordanian universities for human relations among them (university collegiality) as a professional ethical behavior among the rank of (Associate Professor), and each of the professor and Assistant Professor rank, in favor of the Associate Professor rank.

\section{Result Discussion}

\subsection{Discussion of the Result to Question (1)}

What is the degree represent of the faculty members in official Jordanian Universities for the human relation among them (University Collegiality) as a professional ethical behavior?

The results show that the degree represent of the faculty members in official Jordanian Universities for the human relation among them (University Collegiality) as a professional ethical behavior is medium.

This result might be attributed to that university is an open social center for the faculty members, which allow them to find respectful university collegiality, creating a vibrant university environment that enables job satisfaction and achieves through it the university's objectives, through interaction, harmony, and collaboration with their other colleagues because the gateway to interaction between them is human relations (university collegiality).

Faculty members who are in favor of university collegiality with others do communication channels, both verbal and nonverbal, or knowledge based on communication, which widens the participation of the knowledge framework between them, which allows for understanding, contributes to decision-making and provides an important information to each other, communication is a means of social communication, emotional integration, which leads to the university collegiality.

As for the paragraph that received the lowest arithmetic average, it may be attributed to a large number of faculty members, the great administrative responsibilities on them, the official working hours' length, and the delayed teaching lectures, which reduces the chances of having enough time for the colleagues' participation their deferent occasions.

This result was agreed with Aldaya, Abu al-Rish (2017), and al-Otaibi study (2017), as differed with Al Ashqar 
study (2012), Alawneh (2015), Al halalat, and Adaylah (2017).

\subsection{Result Related to Question (2)}

Are there statistically significant differences in the estimates of the study sample members for the degree represent of the faculty members in official Jordanian Universities for the human relations among them (University Collegiality) as a professional ethical behavior, referred to variable of gender, faculty class and academic rank?

The results shows that the views of the male faculty members to the degree which represents the faculty members of the official Jordanian universities for human relations among them (University Collegiality) as a professional ethical behavior were higher than females.

This result may be attributed to that the university reflects the prevailing customs and traditions in society; especially the university education system is influenced by the philosophy of society. The results were agreed with Al-Ashqar and Al-Lauh study (2012), Alawneh study (2015), as well as with the Dirani study, Al-Shadouh (2016), Al Halalat study, Aladayleh (2017), AlDaya study, and Abu Al Rish(2017).

\subsubsection{Result Related to Question (1)}

Are there statistically significant differences in the estimates of the study sample members for the degree represent of the faculty members in official Jordanian Universities for the human relations among them (University Collegiality) as a professional ethical behavior, referred to variable the type of the college?

There are statistically significant differences in the study sample to the degree, which represents the faculty members of the official Jordanian universities for the human relations among them as a professional ethical behavior for the variable of the college type. This indicates that the views of faculty members in the scientific college to the degree which represents the faculty members of the official Jordanian universities for human relations among them (University Collegiality) as a professional ethical behavior were more than humanities colleges. This result is due to the fact that faculty members in scientific colleges tend to deal with issues clearly. Tend to discuss, listen to different views, unlike humanities colleges, which have many controversial views, which lead to weakening the opportunity for human relations among them. This result differed with Al-Ashqar study and Al-louh (2012).

\subsubsection{Result Related to Question (2)}

Are there statistically significant differences in the estimates of the study sample members for the degree represent of the faculty members in official Jordanian Universities for the human relations among them (University Collegiality) as a professional ethical behavior, referred to variable of gender, faculty class and academic rank?

There are statistically significant differences at the significance level (0.05) in the study sample to the degree that represents the faculty members in the official Jordanian universities for human relations among them (university collegiality) as a professional ethical behavior among the rank of (Associate Professor), and each of the professor and Assistant Professor rank, in favor of the Associate Professor rank.

This result may be attributed to the faculty members with the Associate Professor rank are the most capable of interaction, knowledge transfer and they are trying to create a supportive academic environment for collegiality relations, especially since their academic rank is in the middle is between the highest academic rank of professor and the lowest academic level of assistant professor, and their clear competencies in the human performance interacting with all colleagues. This result differed with al Dirani study, Al-Shadouh (2016), Al-Daya and Abu AlRish (2017).

\subsection{Recommendations}

Based on the study's results, the study recommends the following:

- The statistical averages and standard deviations showed that the degree represents faculty members in the official Jordanian universities for human relations among them (university collegiality) as a professional ethical behavior was of a medium degree.So, the study recommends to take into consideration the university collegiality among faculty members.

- Place a charter for university collegiality that is shared by official and non-official Jordanian universities.

\section{References}

Abu Hussein, S. (2014). Improving the Efficiency of Faculty Member: Evaluation the Teaching Performance of Faculty Members at University and its Impact on the Quality of the Higher Education. Amman: Dar Amjad.

Al-Alawneh, O. (2015). The social relations between faculty members and students at the Faculty of Sports 
Sciences at Mu'tah University from the students' perspective. Mu'tah Journal for Research and StudiesHumanities and Social Sciences- Jordan, 1(30), 11-36.

Al-Ashqar, Y., Al-lawh, I., \& Munis, K. (2012). Extent Palestinian universities Faculty Members Use Human relations as Percieved by their Students. The Islamic University Journal of Educational and Psychology Studies, 1(20), 405-435.

Al-Dayeih, Eman Sh., Abu-Reesh, Reem M. (2017). The Degree of the Faculties of Education Practice of the Professional Standard Ethics and Requirement in the Palestinian Universities. Journal of Studies- educational sciences- Jordan, 137-153.

Al-halalat, K. I., Adaiyleh, L., \& Al-Saideh, J. (2017). The Degree of Commitment of Social Work Department Faculties in Jordanian Universities in Teaching Profession Ethics from the Perspective of Students: The university of Jordan and Al- Balqa' Applied University. Journal for Researches- Educational SciencesJordan, 155-171.

Al-Hasan, A. (2017). Ethics of performance proficiency in higher education: case study of Sudanese higher education institutions. International Islamic Marketing Association- London, 1(2), 85-114.

Al-Rawashdeh, A. Z., \& Al-Arab, A. R. (2017). Characteristics of Distinct University Teaching Staff as an Index of Higher Education Quality in Jordan. Arab Magazine for Quality Assurance of Higher Education - Yemen, 10(27), 67-84.

Al-Rubyie, M. (2008). Cooperative Learning Strategies. Iraq: Dar Al-Diya.

Al-Uteybi, A. (2017). The Degree of Faculty Member's Commitment at the Faculty of Education in Al-Dawadmi to the Professional Ethics from the Perspective of their students. Journal of Human and Social Studies University of Wahran- Algeria, 1(7), 55-74.

Al-widyan, S. (2016). Prevailing Human Relations among a Sample of Faculty Members at Salman Bin Abdulaziz University and their Relation with Job Performance. Journal of Educational Sciences- Faculty of EducationAin Shams University- Egypt, 1(40), 427-479.

Balaawi, I. N., \& Ibrahim (2007). The Teaching and its General methods. Amman: Dar Haneen Publishing \& Distributing.

Blankenship, A., Platte, E., \& Hannah, R. (2017). Rewarding Collegiality: The Use of Collegiality as a Factor in Faculty Evaluation and Employment Decisions. Journal of Faculty Development, 2(31), 37-42.

Bruce, M. (2016). Collegiality and Performativity in a Competitive Academic Culture. Higher Education Review, 2(4), 31-50.

Dirani, E., \& AL-Shdooh, W. (2016). The Level of Collegiality among the Faculty Members at the University of Jerash - Jordan (A Case Study). International Journal of Education, 1(4), 33-39.

Sophia, S., \& Kevin, B. (2017). The Impact of Collegiality amongst Australian Accounting Academics on WorkRelated Attitudes and Academic Performance. Studies in Higher Education, 3(42), 411-427.

Terosky, A., \& Lapointe, C. (2015). Supporting Online Faculty through a Sense of Community and Collegiality. Online Learning, 3(19), 147-161.

\section{Copyrights}

Copyright for this article is retained by the author(s), with first publication rights granted to the journal.

This is an open-access article distributed under the terms and conditions of the Creative Commons Attribution license (http://creativecommons.org/licenses/by/4.0/). 